\title{
Brazilian dieticians: professional and demographic profiles ${ }^{1}$
}

\author{
Os nutricionistas brasileiros: perfil \\ profissional e demográfico
}

Rita de Cássia AKUTSU²

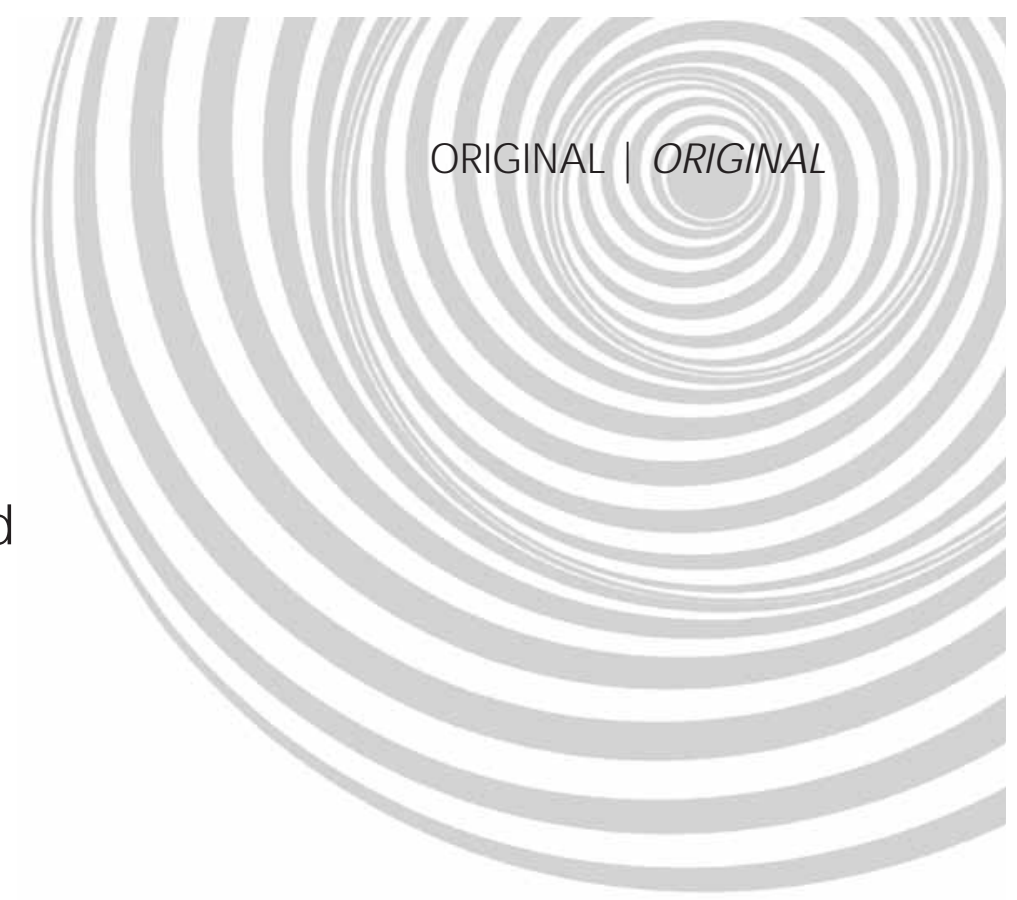

A B S T R A C T

\section{Objective}

The objective of this study was to analyze the difference in Brazilian dieticians' work activities in view of personal, demographic and work variables.

\section{Methods}

This study takes a cross-sectional, exploratory approach with random sample per grouping, and with an accuracy of 0.05 and confidence interval of $95.0 \%$. The final sample was of 587 respondents among a total of 25,793 dieticians. Descriptive (mean, median, standard deviation) and variance (Kruskal Wallis, Spearman index and Chi-square) analysis were performed.

\section{Results}

$46.9 \%$ of the respondents lived in Southeast region of Brazil; $96.9 \%$ were women; $61.2 \%$ had a partner, and the average age was 34.8 years; $51.4 \%$ graduated from public universities, $63.9 \%$ accomplished some kind of post-graduation course; $55.9 \%$ worked in private institutions and $39.7 \%$ had worked in their current job for at least two years; $30.7 \%$ performed their activities in more than one area and $24.4 \%$ worked in food and nutrition units. Variance analysis indicated that there was significant difference in the stratified variables type of institution in which the dieticians graduated from, "year of graduation", "type of organization" in which they work and "time working" stratified by geographic region.

\section{Conclusion}

Typical dieticians are women, young, have a partner, live in the Brazilian Southeast, finished a post-graduate course, perform their activities in more than one area or in food and nutrition units and in private companies.

Indexing terms: Nutritionist. Health occupations. Demographic profile. Professional profile.

\footnotetext{
${ }^{1}$ Article based on the thesis of R. C. C. AKUTSU entitled "Valores e Bem-estar dos Nutricionistas Brasileiros (Values and Wellbeing of Brazilian Dieticians). Faculdade de Saúde da Universidade de Brasília". (School of Health of the University of Brazilia).

2 Universidade Federal de São Paulo, Escola Paulista de Medicina, Departamento de Medicina Preventiva. R. Borges Lagoa, 1341, VI. Clementino, 04055-110, São Paulo, SP, Brasil. E-mail: <rita_akutsu@yahoo.com.br>.
} 


\section{RESU M O}

\section{Objetivo}

O objetivo deste trabalho foi analisar a diferença de atuação dos nutricionistas brasileiros em face das variáveis pessoais, demográficas e de trabalho.

\section{Métodos}

Trata-se de estudo transversal exploratório com amostra aleatória por agrupamento com precisão de 0,05 e intervalo de confiança de 95\%. A amostra final foi de 587 respondentes do total de 25793 profissionais. Realizou-se análise descritiva (média, mediana e desvio-padrão) e de variância (Kruskal Wallis, Índice de Direção da Associação de Spearman e Qui-quadrado).

\section{Resultados}

Dos respondentes, $46,9 \%$ residiam no Sudeste; $96,9 \%$ eram do sexo feminino; $61,2 \%$ referiram ter companheiro(a); a média de idade da amostra foi de 34,8 anos; $51,4 \%$ graduaram-se em uma instituição pública; $63,9 \%$ tinham algum tipo de pós-graduação; 55,9\% trabalhavam em empresas privadas; $39,7 \%$ tinham até dois anos no emprego atual; 30,7\% desenvolviam suas atividades em mais de uma área e $24,4 \%$ trabalhavam na Produção. As análises de Variância apontaram que há diferença significativa no "tipo de instituição" em que concluíram a graduação, "tempo de formado", "tipo de organização" em que trabalha, e "tempo de trabalho" estratificado por região geográfica.

\section{Conclusão}

O profissional nutricionista típico é mulher, jovem, com companheiro, morador do Sudeste, pós-graduado, atua em mais de uma área ou na produção de refeições e desenvolve suas atividades em empresas privadas.

Termos de indexação: Nutricionista. Ocupações em saúde. Perfil demográfico. Perfil profissional.

\section{INTROD U CTIO N}

The emergence and development of the dietician profession in many countries has not been uniform; the heterogeneity with which the professional activities of this class are being organized seems to be related, especially, to the needs and opportunities that emerge in each country. That is, it was in an industrialized and urbanized scenario characterized by concentrated economic activities, long work shifts and little time for leisure and rest that the dietician profession consolidated, inserting the individual in the working world ${ }^{1}$.

The entrance of women in the workforce around the world, especially in Brazil, was one of the most marking social changes that took place since 1970. From 1980 onwards, the participation of economically active women (PEA) jumped from $31.2 \%^{2}$ to $42.4 \%$ in $2001^{3}$ in Brazil, suggesting that this trend is irreversible.
Regarding dieticians, data show that it is a predominantly female profession $196.0 \%$ of the workers are females) ${ }^{(3)}$ from the beginning ${ }^{4}$, which, in a working environment characterized by inequalities where women are paid less and have fewer social rights, their wellbeing is at risk ${ }^{5}$.

To complement this scenario, State policies regarding education, health and work also determine the emergency, consolidation, evolution and amplified reproduction of this profession in Brazil. Bosi ${ }^{6}$ adds that since its creation, the profession already faced barriers in the search for technical autonomy. The author blames the low determination and participation of the category, low autonomy because of competition with nutrologists, little prestige attributed to the class and the difficulty to delineate the objectives of the profession.

On the other hand, the first studies by Tilly $\& \operatorname{Scott}^{7}$ showed the forms and the variety of strategies in which women conciliate family or

${ }^{3}$ According to data collected for this research in the Regional Dietician Councils. 
home tasks with "productive" work ${ }^{(4)}$. The authors point out that the redefinition that occurred in the female role after World War II may have been one of the most generalized and permanent in the West in the 20th Century. In Brazil this redefinition reached an expressive peak in 1970 and manifested in the expansion of female labor, especially among married women ${ }^{8}$.

Given the broadening in the range of the activities performed by women, there was a more marked access of women in more qualified jobs and jobs with more prestige, resulting in a virtuous growth of job levels and education ${ }^{8}$. Still it remained far from the levels achieved by men.

It is also necessary to point out the advances of the legislation regarding the search for equality of job opportunities and opposition to discrimination of female workforce ${ }^{8}$. The advances mentioned place the female dietician as an active and passive participant of this scenario, of fighting discrimination, as the profession is predominantly female.

Work and family are the spinal cord of human existence. Both are also the main sources of physical, psychological and social demands, given the high degree of compromise and dedication that they require ${ }^{9}$. In this sense, the work theme is extremely important for systemically comprehending current life, especially in big working centers, since it can contribute to the search of more adaptive and balanced ways to manage the health needs of an individual and his/her family, of the organization that employs him/her and of society as a whole ${ }^{10}$.

According to Morin ${ }^{11}$, for a work to have sense, it is important for the person who carries out the work to know where the work leads to. In other words, it is essential that the objectives of the work are clear and that its results are valuable for those who perform it.

In a changing scenario, it is important to identify the dietician and his/her education. Thus, the objective of this work is to investigate the personal, demographic and work characteristics of dieticians in order to know the differences between the activities they perform and how they place themselves in the workforce.

It is important to mention that this study is of probabilistic character and contemplates the personal and demographic characteristics. Historical comparisons were not done because other similar studies were not found on dieticians although some studies have been used to contrast the data obtained. However, the importance of this research is that it will be a reference for future studies that contemplate areas such as the health, wellbeing, quality of life at work, labor market and so on of the workers.

\section{METHODS}

The design of the present study, of an exploratory cross-sectional character, was chosen because it is the best to investigate personal, demographic and working characteristics of dieticians, taking into account the variety of perspectives that the theme demands.

The size of the probabilistic sample was defined by adopting an accuracy of 0.05 and a confidence level of $95 \%$ for a normal distribution and estimation of population proportion ${ }^{12}$. The final sample, random and stratified by geographical region, consisted of 587 individuals fully employed in all regions of the country. The participants were chosen from the list of dieticians registered in the Regional Councils of Nutrition (CRN).

The number of letters we received was proportional to the number of letters we sent. Random sampling stratified by geographical region respected the initial number of dieticians listed in the CRNs in each state of the federation.

Each individual who participated in this research received a letter of presentation of the study along with a Free and Informed Consent

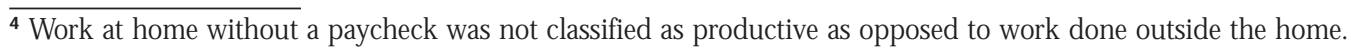


Form. A signed copy of this form remained with the team responsible for the research and the other copy stayed with the participant.

With the objective of investigating if there is a difference between the dieticians in function of geographical region, gender, marriage status, age institution from which they graduated, education level, type of organization in which they work, time working and activity area, a questionnaire whose items correspond to the variables mentioned was created and applied (Attached).

The data were prepared for multivariate analysis that verifies the requisites needed to minimize the occurrence of statistical decision errors. The identification and treatment of the outliers occurred in all variables and for those who were characterized as such, a recodification was done, canceling their effect on the distribution or taking them out of the analyses.

Statistical analysis of the data with a descriptive nature (frequency, mean, percentage and mean deviation) was done to characterize the sample, in addition to analysis of variance (Kruskal Wallis, Spearman Direction Association Index and Chi-Square).

All the tests were done with the aid of the Statistical Package for Science (SPSS), version 13.0.

The initial sample consisted of 654 dieticians who replied to the mail they received. However, five questionnaires $(0.8 \%)$ were eliminated because they were not filled out or filled out in an incomprehensible manner.

We verified that out of the 649 dieticians whose questionnaires were considered valid, 23 $(3.5 \%)$ were unemployed, two $(0.3 \%)$ were retired and one $(0.2 \%)$ was on a medical license for more than two years; they were excluded from the sample, resulting in 623 questionnaires.

Regarding data analysis, we verified the needed requirements to minimize the occurrence of statistical decision errors. The presence of multivariate outliers was verified by means of a standard linear regression of which by the criterion of the distance of $M$ ahalanobis we have $\left.\left[\chi_{(9)}^{2}=27.88 ; p \leq 0.001\right)\right]$. The discrepant cases were taken out of the sample. The final sample consisted of 587 subjects.

The research was done according to the ethical principles of the Declaration of Helsinki (2000) and the norms of the Resolution 196/96 of the National Council of Health, taking into account their laws regarding the ethical aspect of research with human beings. The project was submitted to and approved by the Research Ethics Committee of the School of Health Sciences of the Universidade de Brasília (protocol 015/2004).

\section{RE S U LTS}

The questionnaires of 587 dieticians were assessed. The subjects of the final sample were distributed as follows: Central-West: 42 professionals; South: 131 professionals; Southeast: 273 professionals; North 38: professionals and Northeast: 103 professionals.

Of the valid questionnaires, the Southeast region had the highest number of dieticians $(46.5 \%)$ and the North and Central-West regions had the lowest $\cong 7.0 \%$ ) number.

The mean age of the sample was 34.8 years with a range that varied from 21 to 70 years and standard deviation (SD) of 9.3 years. It is important to point out that $42.5 \%$ of the sample aged from 20 to 30 years and that only $4.8 \%$ were above 50 years.

Most of the dieticians $(96.9 \%)$ were females, $61.2 \%$ reported having a partner and being within 20 to 30 years old $(43.4 \%)$.

The male dieticians also had partners $(60.0 \%)$, aged from 31 to 40 years $(50.0 \%)$ and $75.0 \%$ of them graduated from public universities.

When asked what kind of institution the dieticians had graduated from, $51.4 \%$ reported having graduated from public universities. This percentage rises to $80.6 \%$ for those who graduated until 1980 . The tests reveal that in the 
North, Northeast and Central-West regions most professionals studied in public institutions and that in the South and Southeast regions most finished their graduation in a private institution. This result was statistically significant $\left[\chi_{(4)}^{2}=142.869\right.$; $\mathrm{p} \leq 0.001]$.

There was also a significant difference in the variable Time since Graduation $\left[\chi_{(12)}^{2}=32.403\right.$; $p \leq 0.001$ ] by geographical region. The professionals who graduated between 1991 and 2000 prevailed in most regions and in two of them, Central-West and South, most had graduated 5 years ago (graduated between 2001 and 2005).

M ost of the dieticians $(63.9 \%)$ had some sort of post-graduate degree (Table 1 ). What can be pointed out is that there was no significant difference by geographical region regarding education level $\left[\chi_{(8)}^{2}=5.415 ; p \geq 0.712\right]$, even when they are compared with different statistical indices (Kruskal Wallis and chi-square).

Differently from female dieticians, most male dietician did not have any post-graduate degree $(65.0 \%)$.

M ost of the dieticians (55.9\%) worked in private companies (Table 2). However, in the South and Southeast regions, the number of professionals working for private companies exceeded the number of those who worked for public companies. Most of the male dieticians $(55.0 \%)$ worked for private companies and had been working in the same place for up to 2 years $(50.0 \%)$.
Table 1. Distribution of Brazilian dieticians by education level and geographical region. Brazil, 2005.

\begin{tabular}{|c|c|c|c|c|c|c|}
\hline \multirow{3}{*}{$\begin{array}{l}\text { Geographical } \\
\text { region }\end{array}$} & \multicolumn{6}{|c|}{ Education level } \\
\hline & \multicolumn{2}{|c|}{ Graduation } & \multicolumn{2}{|c|}{ Specialization } & \multicolumn{2}{|c|}{ M asters/doctorate } \\
\hline & $\mathrm{n}$ & $\%$ & $\mathrm{n}$ & $\%$ & $\mathrm{n}$ & $\%$ \\
\hline North & 15 & 39,5 & 17 & 44,7 & 6 & 15,8 \\
\hline Northeast & 40 & 38,8 & 52 & 50,5 & 11 & 10,7 \\
\hline Central-west & 12 & 28,6 & 22 & 52,4 & 8 & 19,0 \\
\hline Southeast & 93 & 34,1 & 133 & 48,7 & 47 & 17,2 \\
\hline South & 52 & 39,7 & 63 & 48,1 & 16 & 12,2 \\
\hline Brazil & 212 & 36,1 & 287 & 48,9 & 88 & 15,0 \\
\hline
\end{tabular}

When the types of organization were compared with different statistical indices (Kruskal Wallis and chi-square) the differences in percentage between the Types of organization in which they worked by geographical region were significant $\left[\chi_{(12)}^{2}=59.719 ; p \geq 0.001\right]$, which showed that in the North, Northeast and Central-West regions, most dieticians were predominantly in the public sector, different from the national mean.

Regarding Time Working in the current organization (Table 3), the results reveal that, in general, there was a trend of statistically significant differences, with a higher rate of dieticians with 2 to 5 years and most $(66.3 \%)$ having worked in their current job for up to 5 years. This trend was confirmed by Spearman 's direction of association index $=0.082(p \leq 0.046)$ for ordinal data (Table 3$)$.

Regarding the Activities Performed, it is important to point out that even though many

Table 2. Distribution of Brazilian dieticians by type of organization in which they work and geographical region. Brazil, 2005*.

\begin{tabular}{|c|c|c|c|c|c|c|c|c|}
\hline \multirow{3}{*}{ Geographical region } & \multicolumn{8}{|c|}{ Type of organization } \\
\hline & \multicolumn{2}{|c|}{ Private } & \multicolumn{2}{|c|}{ Public } & \multicolumn{2}{|c|}{ Mixed economy } & \multicolumn{2}{|c|}{ More than one organization } \\
\hline & $\mathrm{n}$ & $\%$ & $\mathrm{n}$ & $\%$ & $\mathrm{n}$ & $\%$ & $\mathrm{n}$ & $\%$ \\
\hline North & 11 & 29,0 & 17 & 44,7 & 3 & 7,9 & 7 & 18,4 \\
\hline Northeast & 43 & 41,7 & 45 & 43,7 & 4 & 3,9 & 11 & 10,7 \\
\hline Central-west & 12 & 28,6 & 23 & 54,8 & 3 & 7,1 & 4 & 9,5 \\
\hline Southeast & 172 & 63,0 & 71 & 26,0 & 14 & 5,1 & 16 & 5,9 \\
\hline South & 90 & 68,7 & 23 & 17,6 & 12 & 9,2 & 6 & 4,6 \\
\hline Brazil & 328 & 55,9 & 179 & 30,5 & 36 & 6,1 & 44 & 7,5 \\
\hline
\end{tabular}

* The variable Type of Organization includes the subcategories: Public Organization, Private Organization, Organization of Mixed Economy and More than one Organization for professionals that perform their activities in more than one company, whatever these activities may be. 
professionals were working in diverse areas, such as Sports Nutrition $(0.5 \%)$, Food Marketing $(0.7 \%)$, Daycare $(0.3 \%)$, Research $(0.5 \%)$, Sanitary Surveillance $(0.5 \%)$, Administration/ Commerce $(1.2 \%)$, Sales $(0.5 \%)$, Epidemiological Surveillance $(0.2 \%)$, Consultancy $(0.7 \%)$, Advisement $(0.3 \%)$, Aesthetics $(0.2 \%)$ and Food Analysis $(0.9 \%)$, it was the most traditional areas (Clinic, Production, Social and Teaching) that concentrated the highest number of professionals.

Another data regarding the Activities Performed (Table 4) that caught our attention was the fact that, in isolation, the highest percentage
$(30.6 \%)$ was that of professionals who worked in more than one area followed by the area of production $(24.4 \%)$. When compared by different statistical indices (Kruskal Wallis and chi-square), the differences in percentage by Activities Performed and geographical region were not significant $\left[\chi_{(20)}^{2}=23.378 ; p \geq 0.271\right]$.

The data also reveal that among the professionals who worked in more than one area (Table 5), most of them performed these different activities in the same company, usually private $(41.7 \%)$.

Table 3. Percentage distribution of the dieticians by time working in current job and geographical region. Brazil, 2005.

\begin{tabular}{|c|c|c|c|c|c|c|c|c|c|c|}
\hline \multirow{3}{*}{ Geographical region } & \multicolumn{10}{|c|}{ Time working } \\
\hline & \multicolumn{2}{|c|}{ Up to 1 year } & \multicolumn{2}{|c|}{$>1$ to 2 years } & \multicolumn{2}{|c|}{$>2$ to 5 years } & \multicolumn{2}{|c|}{$>5$ to 10 years } & \multicolumn{2}{|c|}{10 years } \\
\hline & $\mathrm{n}$ & $\%$ & $\mathrm{n}$ & $\%$ & $\mathrm{n}$ & $\%$ & $n$ & $\%$ & $\mathrm{n}$ & $\%$ \\
\hline North & 7 & 18,4 & 8 & 21,1 & 11 & 28,9 & 3 & 7,9 & 9 & 23,7 \\
\hline Northeast & 19 & 18,4 & 1 & 18,4 & 24 & 23,3 & 10 & 9,7 & 31 & 30,1 \\
\hline Central-west & 9 & 21,4 & 8 & 19,0 & 9 & 21,4 & 8 & 19,0 & 8 & 19,0 \\
\hline Southeast & 41 & 15,0 & 59 & 21,6 & 84 & 30,8 & 43 & 15,8 & 46 & 16,8 \\
\hline South & 34 & 26,0 & 29 & 22,1 & 28 & 21,4 & 19 & 14,5 & 21 & 16,0 \\
\hline Brazil & 110 & 18,7 & 123 & 21,0 & 156 & 26,6 & 83 & 14,1 & 115 & 19,6 \\
\hline
\end{tabular}

Table 4. Distribution of Brazilian dieticians by activities performed and geographical region. Brazil, 2005.

\begin{tabular}{|c|c|c|c|c|c|c|c|c|c|c|c|c|}
\hline \multirow{3}{*}{ Geographical region } & \multicolumn{12}{|c|}{ Activities performed } \\
\hline & \multicolumn{2}{|c|}{ Production } & \multicolumn{2}{|c|}{ Clinic } & \multicolumn{2}{|c|}{ Social } & \multicolumn{2}{|c|}{ Teaching } & \multicolumn{2}{|c|}{ More than one area } & \multicolumn{2}{|c|}{ Other areas } \\
\hline & $\mathrm{n}$ & $\%$ & $\mathrm{n}$ & $\%$ & $\mathrm{n}$ & $\%$ & $\mathrm{n}$ & $\%$ & $\mathrm{n}$ & $\%$ & $n$ & $\%$ \\
\hline North & 6 & 15,8 & 9 & 23,6 & 6 & 15,8 & 2 & 5,3 & 13 & 34,2 & 2 & 5,3 \\
\hline Northeast & 23 & 22,3 & 17 & 16,5 & 12 & 11,7 & 5 & 4,9 & 39 & 37,9 & 7 & 6,8 \\
\hline Central-west & 10 & 23,8 & 6 & 14,3 & 8 & 19,0 & 7 & 16,7 & 10 & 23,8 & 1 & 2,4 \\
\hline Southeast & 71 & 26,0 & 63 & 23,1 & 23 & 8,4 & 16 & 5,9 & 80 & 29,3 & 20 & 7,3 \\
\hline South & 33 & 25,2 & 34 & 26,0 & 11 & 8,4 & 7 & 5,3 & 38 & 29,0 & 8 & 6,1 \\
\hline Brazil & 143 & 24,4 & 129 & 22,0 & 60 & 10,2 & 37 & 6,3 & 180 & 30,6 & 38 & 6,5 \\
\hline
\end{tabular}

Table 5. Distribution of the dieticians who perform two activities by type of organization and geographical region. Brazil, 2005.

\begin{tabular}{|c|c|c|c|c|c|c|c|c|}
\hline \multirow{3}{*}{ Geographical region } & \multicolumn{8}{|c|}{ Type of organization } \\
\hline & \multicolumn{2}{|c|}{ Private } & \multicolumn{2}{|c|}{ Public } & \multicolumn{2}{|c|}{ Mixed economy } & \multicolumn{2}{|c|}{ More than one organization } \\
\hline & $\mathrm{n}$ & $\%$ & $\mathrm{n}$ & $\%$ & $\mathrm{n}$ & $\%$ & $\mathrm{n}$ & $\%$ \\
\hline North & 2 & 15,4 & 4 & 30,8 & 1 & 7,7 & 6 & 46,1 \\
\hline Northeast & 8 & 20,5 & 21 & 53,9 & - & - & 10 & 25,6 \\
\hline Central-west & 2 & 20,0 & 4 & 40,0 & - & - & 4 & 40,0 \\
\hline Southeast & 43 & 53,7 & 20 & 25,0 & 6 & 7,5 & 11 & 13,8 \\
\hline South & 20 & 52,6 & 6 & 15,8 & 5 & 13,2 & 7 & 18,4 \\
\hline Brazil & 75 & 41,7 & 55 & 30,5 & 12 & 6,7 & 38 & 21,1 \\
\hline
\end{tabular}




\section{ISCUSSIO N}

The data reveal that the Southeast region of Brazil concentrated the highest number of dieticians $(46.5 \%)$ in disagreement with the population distribution $(42.6 \%)^{13}$. This difference is due to two factors: the presence of the highest concentration of industries in the Southeast and their professional link (technical responsibility) with programs like PAT (Worker's Food Program) ${ }^{14}$ and the time of existence of graduation courses in the Southeast together with the emergence of more graduation courses in this region ${ }^{15}$, mostly in private institutions. This increase in the number of graduation vacancies happened because of a social demand for more higher education schools and the public institutions did not respond to this demand.

The benefits of education to improve the income of workers cannot be argued. In a recent report on the inequality in Brazil, the World Bank/ IPEA ${ }^{16}$ showed that as new graduates entered the workforce, the inequality dropped given the better distribution of education since the younger generations had a less unequal distribution of education. The improvement in total inequality depended, thus, of two factors: the size of the generation that enters (quantity) and the equality of education of this generation (quality) ${ }^{16}$.

Crespo \& Reis ${ }^{17}$ showed that the conclusion of education stages have significant effects on income. Therefore, not only each extra year in education grants a certain percentage increase in income, but this gain can be very significant if this year is associated with a full stage, for example, completing elementary or high school. For a complete elementary, the individual gains roughly $15.0 \%$ more. For a complete high school and university degree, the gains are $18.0 \%$ and $23.0 \%$ respectively. Furthermore, the results show that the impact of education on income is higher as more years of formal education are accumulated by the individual. The results of the Conselho Federal de Nutricionistas (CFN) ${ }^{18}$ confirm these studies when they state that $16.3 \%$ of the interviewed dieticians had a raise in salary after they attended some sort of post-graduation course, whether it was lato sensu or stricto sensu.

The data or the percentage distribution of masters and doctors of the Central-West region evidenced that, proportionally, this is the region with the highest percentage of qualified professionals. The percentage distribution of masters and doctors in all regions show that the Southeast has the highest percentage $(53.4 \%$ ) of these education degrees, and this is compatible with the availability of post-graduation courses in this region $(55.2 \%)^{19}$.

The discussions regarding changes in the availability of vacancies in nutrition courses and the contents of these courses have been frequent sources of preoccupation and debate by councils of the category, student entities, unions and entities linked with nutrition. The results of these discussions have been reformulated curriculums, broadening of the actions done by entities regarding public policies and inspection of professional activities, visibility of the category in society, and the strengthening of the institutions linked to the category.

Literature states that education gained shape at the end of the 19th Century as an opportunity for women to enter the workforce.

Despite conquering the right to formal education and a profession, these conquers were restricted. According to Almeida ${ }^{20}$, men dominated formal education and established the rules and norms of female instruction, limiting their access to professions determined by them. Areas such as domestic economy, cooking, etiquette, artistic design, childcare and handcraft, and later, activities of the health sector were " reserved" for women.

Thus nutrition can be pointed as a profession that remained a "female profession" $(96,9 \%)$. A similar result was found by the Coordenação de A perfeiçoamento de Pessoal de Nível Superior ${ }^{19}$ which reports $96,5 \%$ of female professionals. Even after 60 years of the creation 
of the first graduation course, the profession remains dominated by females. Such data show that, despite all this time, the studies done by Padilha ${ }^{21}$ and Andrade $\&$ Lima ${ }^{22}$ remain current. These studies show that, when choosing female professions, there is an articulation between house work and professional work, mixing the home environment with the work environment leading women to be unable to distinguish between the two. These choices would also be linked to attributes that are intrinsic to the female nature and services that circle about house tasks, such as nutrition, cleaning and clothing. These results are corroborated by studies of Instituto Brasileiro de Geografia e Estatística ${ }^{3}$ data, Barros et al. ${ }^{23}$ and by Lavinas et al. ${ }^{24}$.

Despite the difficulties pointed out by the researchers, the entrance of women in the workforce improved both quantitatively, as female participation rose, and qualitatively, by having access to positions that were once exclusive to males. Still, as revealed before, women have not yet reached the point at which men are. Regarding the quantitative dimension, Barros et al. ${ }^{23}$ showed that female participation increased by roughly 30 percentage points in the last two decades in Brazil (this result refers to the comparison of participation of women of the same age in different birth cohorts).

Roughly half of the professionals age from 20 to 30 years, which shows that the dietician is generally young and that the number, type of postgraduation and activity area can be influenced by this variable. Furthermore, the predominance of this age range can also be attributed to the steep increase in the number of nutrition graduation courses in the last decade, which jumped from 45 courses in 1996 to 269 courses in $2006^{15}$, representing a growth of roughly $500 \%$ in the number of vacancies.

The fact that most professionals have a partner only confirms that, in Brazil, from the 1970 's onward, the expansion of female activities and specially that of married women ${ }^{8}$ also happened among dieticians.
Regarding the unemployment rate, while this rate among dieticians is of $3.5 \%$, the mean percentage rate of unemployment in the six metropolitan regions is of $12.1 \%$. Among women, the rate is $22.2 \%$ and among those who have 12 or more years of formal education, it is of $3.9 \%{ }^{25}$. These results show that, although the salary of dieticians is not high, being roughly 4.3 minimum wages $^{18}$, unemployment among dieticians was lower than the percentages listed above. It is possible that this favorable employment rate is due to the fact that dieticians can work in more than one organization $(7.5 \%)$ and in more than one area $(30.6 \%)$. Furthermore, we discovered that among dieticians that work in more than one area, most of them $(78.9 \%$ ) perform these different tasks in the same organization (Table 5).

When we look closer at the differences between the Type of Organization and the Year of Graduation, we verify that most of the dieticians who graduated between 1950 and 1980 had been working for more than 10 years $(66.7 \%)$ in public companies $(69.4 \%)$. Those who graduated between 1981 and 1990 had been working for more than 10 years $(52.1 \%)$ both in private $(44.5 \%)$ and in public companies $(41.8 \%)$.

The fact that the dieticians who had graduated earlier were working in public companies seems to reflect the search of these professionals for more stable jobs as they advance in their careers.

Another point to be noticed is that, although the professionals have been searching for alternatives, new opportunities, in the labor market (two jobs, two activities) the most traditional areas reveal the strength of the market and were consistent with the areas that are privileged in graduation courses ${ }^{15}$. Here it is also important to point out the precariousness of the work evidenced by two jobs/activities (30.6\%) possibly because the mean wages were below the needs of these professionals ${ }^{18}$. These data regarding wages confirm the motivations indicated by the dieticians in the study mentioned ${ }^{18}$ for the migration of area of activity (low wages, lack of 
work perspective, qualification in another area, competition in the area, weak market, personal preference and opportunity) and also corroborate the findings on worsening of the female work. Given the methodology adopted by $\mathrm{CFN}^{18}$ who grouped the dieticians by administrative region ${ }^{(5)}$, it was not possible to compare them by geographical region.

Although private companies were the most frequent employers $(55.9 \%)$, the number of dieticians who worked for public companies $(30.5 \%)$ was significant, especially if we consider that in the Northeast and in the Central West this percentage reached almost $50 \%$ of the professionals. When analyzed in further detail, the results show that in all regions the professionals who worked in private companies usually worked in the production area. Those who worked in public companies were usually in the clinical and social areas and in similar percentages, except for the Southern region, whose results were $13.0 \%$ and $39.1 \%$ respectively. Common sense prevails in public companies where the production of meals is outsourced.

Approximately $40.0 \%$ of the dieticians were in the current job for at most two years, which may indicate that these numbers were due to both the increase in the number of dieticians seen in the last 5 years ${ }^{15,18}$, and the precariousness of the female work identified by Lavinas et al. ${ }^{24}$, whose study shows the vulnerability of women to the variability of economic activity, besides the volatility of female work positions. The authors reveal that the fluctuations in the GDP (gross domestic product) had different impacts on the various employment rates, by gender and education level, showing that a university diploma is a protecting factors towards unemployment, at least in times of little growth ${ }^{25}$.

Given the migration of activity area pointed out by Conselho Federal de Nutricionista ${ }^{18}$, mentioned earlier in this work, and of the discovery of this study of the significant percentage of professionals with two jobs and two areas of work, the formation of a generalist professional seems to be, in fact, the best option for graduation courses as these will supply the necessary tools for diverse activities and/or changes in activity areas.

Before these discussions on employment, the professional qualification sought by some dieticians shows that the competitiveness and updating of these professionals can be the reason for the low unemployment rates (3.5\%) and yet, that there is understanding on the part of the dieticians of the new paradigms of the employment world, which require flexibility and high motivation ${ }^{1}$.

\section{CONCLUSION}

The results of this study confirm earlier studies that indicate that dieticians, since they are mostly females and young, enter the workforce with fewer chances of being paid salaries and having social and labor rights equal to those of men.

Similar to the work of other professionals, the work of the dietician suffers challenges that are inherent to a changing world. However, it seems more protected (low unemployment rate) than other professionals with higher education and especially than women with the same formal education level.

Sixty years after the creation of the profession, the paths of nutrition and of dieticians still remain surrounded by issues of gender that determine the construction of the female identity.

\section{REFEREN CES}

1. Akutsu RC. Valores organizacionais e atenção dietética: estudo de caso em empresas petro-

\footnotetext{
$\overline{5}$ When the research was done, Brazil was divided into 7 administrative regions. Currently there are 8 regions and since São Paulo and Mato Grosso do Sul belong to CRN 3, it is not possible to compare the 5 geographical regions and the administrative regions since CFN supplied only grouped data.
} 
químicas de Sergipe [dissertação]. Salvador: Universidade Federal da Bahia; 2001.

2. Fundação Instituto Brasileiro de Geografia e Estatística. Anuário estatístico do Brasil. Rio de Janeiro: IBGE; 1996.

3. Fundação Instituto Brasileiro de Geografia e Estatística. Pesquisa mensal de emprego [acesso em 15 jan 2007]. Disponível em: <htpp://www. ibge.gov.br>.

4. Costa NM. Revisitando os estudos e eventos sobre a formação do nutricionista. Rev Nutr. 1999; 12(1): 5-19.

5. Antunes R, Alves G. As mutações no mundo do trabalho na era da mundialização do capital. Educ Soc. 2004; 25(87):335-51.

6. Bosi MLM. Definindo fronteiras: o nutricionista e sua profissionalização [tese]. Rio de Janeiro: Escola Nacional de Saúde Pública; 1995.

7. Tilly L, Scott J. Les femmes, le travail et la famille. Paris: Rivages; 1987.

8. Oliveira ZLC. Tempo de mudança: o trabalho de escritório sob novas configurações e antigos formatos (os dilemas da cidadania das mulheres) [tese]. Rio de Janeiro: Instituto Universitário de Pesquisa do Rio de Janeiro; 1997.

9. Pittman J. Work/family fit as a mediator of work factors on marital tension: evidence from the interface of greedy institutions. Hum Relations. 1994; 47(2):183-209.

10. Alvaro JL, Páez D. Psicología social de la salud mental. In: Alvaro JL, Torregrosa JR, Garrido Luque A. Psicología social aplicada. Madrid: M cGraw-Hill; 1996.

11. Morin EM. Os sentidos do trabalho. RAE - Rev Adm. 2001; 41(3):8-19.

12. Costa Neto PLO. Estatística. São Paulo: Edgard Blücher; 1977.

13. Instituto Brasileiro de Geografia e Estatística. Censo demográfico 2000. Rio de Janeiro; 2001.
14. Vasconcelos FAG. O nutricionista no Brasil: uma análise histórica. Rev Nutr. 2002; 15(2):127-38.

15. Brasil. Ministério da Educação. Cadastro das instituições de educação superior [acesso em 15 jan 2007]. Disponível em: <htpp://w ww.educacao superior.inep.gov.br>.

16. Banco Mundial. Empregos no Brasil: relatório no 24408-BR. Rio de Janeiro: IPEA; 2002.

17. Crespo A, Reis MCO. Efeito-diploma no Brasil. IPEA-Notas Técnicas [acesso em 9 abr 2007]. Disponível em: <htpp://www.ipea.gov.br>.

18. Conselho Federal de Nutricionistas. Perfil dos profissionais de nutrição: análise Global. ACTO Estudos, Projetos e Pesquisas. Salvador; 2005.

19. Coordenação de Aperfeiçoamento de Pessoal de Nível Superior. Estatística [acesso em 10 abr 2007]. Disponível em: <http://www.capes.gov.br>.

20. Almeida JS. Mulher e educação: a paixão pelo possível. São Paulo: Fundação Editora da Unesp; 1998.

21. Padilha M ICS. O resgate das raízes: a influência da formação familiar e social na escolha e exercício da enfermagem [dissertação]. Rio de Janeiro: Universidade do Estado do Rio de Janeiro; 1990.

22. Andrade LP, Lima ES. A formação e a prática do nutricionista: o gênero nas entrelinhas. Nutrire: Rev Bras Alim Nutr. 2003; 26:109-26.

23. Barros RP, M enezes NA, Santos DD. Family structure and family behavior over the life cycle in Brazil. Rio de Janeiro: IPEA; 1999.

24. Lavinas L, Barros FB, Amaral MR. Evolução do desemprego feminino nas áreas metropolitanas. Econ Soc. 1999; 12:143-71.

25. Departamento Intersindical de Estatística e Estudos socioeconômicos. Anuário dos trabalhadores 2006. 7a.ed. São Paulo [acesso em 22 jan 2007]. Disponível em: <htpp://www.dieese.org.br>.

Received on: 22/5/2005

Final version resubmitted on: 30/8/2007 Approved on: 4/12/2007 
OS NUTRICIONISTAS | 17

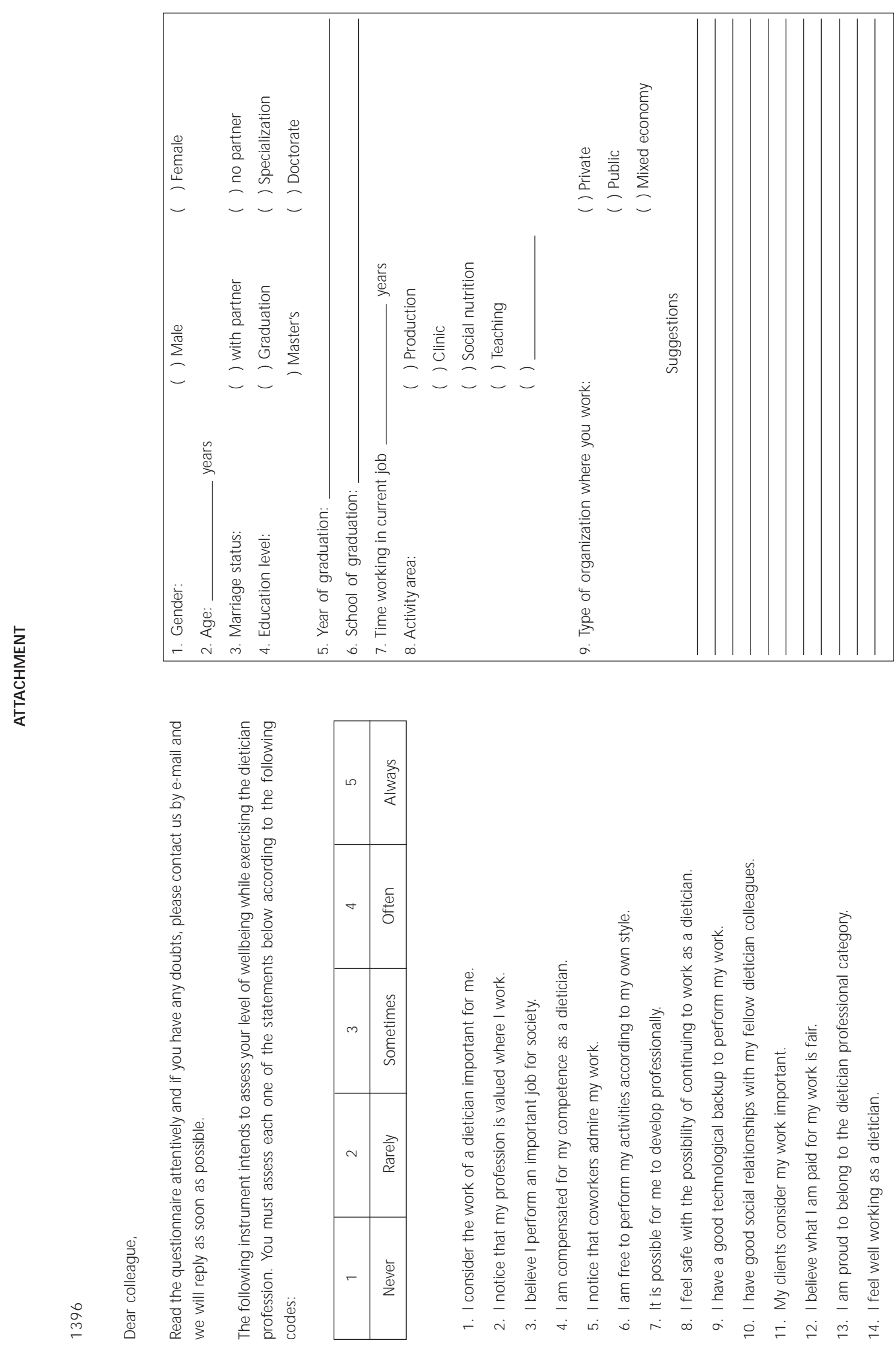


Dear colleague,

In this questionnaire, you need to ask yourself: "What values are important FOR ME as the main quides of MY LFE and what values are least important FOR ME?" There is a list of values in the following pages. These values come from different cultures. Each value is explained in parenthesis right after the word and the explanation may help you understand its meaning. Your task is to assess how important each value is for you as a principle that quides your life. Use the assessment scale below:

As a principle that guides my life, this value is

\begin{tabular}{|c|c|c|c|c|}
\hline 1 & 2 & 3 & 4 & 5 \\
\hline Not important & Little important & Important & Very important & Extremely important \\
\hline
\end{tabular}

The higher the number $(1,2,3,4,5)$, the more important is the value as a principle that guides your life. Try to differentiate as much as possible the values among themselves using all the numbers. Obviously you can repeat the numbers in your answers/assessments.

1 _EQUAUTY (equal opportunity for everyone)

2 _ HARMONY (being at peace with yourself)

3 SOCIAL POWER (control others, dominance)

PLEASURE (satisfying your desires)

FREEDOM (freedom to act and think)

6 - WORK (dignifying way to make money)

7 _ A SPIRTUAL UFE (emphasis in spiritual matters)

8 _FEEUNG OF BELONGING (feeling that others care about me)

9 SOCIAL ORDER (stability in society)

10__ AN EXCITING UFE (stimulating experiences)

11 _ SENSE IN LFE (an objective in life)

12 _ POUTENESS (good manners)

13 RICHES (material possessions, money)

14 NATIONAL SECURTY (protection of my country against enemies)

15 _ SELF-RESPECT (trust my own value)

16 _ REIRIBUTION OF FAVORS (paying back debts)

17 CREATIVITY (imagination, uniqueness)

18 APPEARANCE (make sure you always look well)

19 _ A WORLD OF PEACE (free from wars and conflicts)

20 _ RESPECT FOR TRADITON (preserve the current habits for a long time)

21 MATURE LOVE (profound emotional and spiritual intimacy)
22 _SEF-DISCIPUNE (self-restriction, resist temptation)

23 PRIVACY (the right to have a space of your own)

24 FAMILY SAFETY (protection for your family)

25 _SOCIAL ACKNOWLEDGEMENT (respect, approval by others)

26 _ UNION WITH NATURE (integration with nature)

27 A VARIED UFE (full of desires, news and changes)

28 _WISDOM (mature understanding of life)

29 _ AUTHORTY (the right to lead or give orders)

30_ TRUE FRIENDSHIP (close and supporting friends)

31 A WORD OF BEAUTY (splendor of nature and the arts)

32 SOCIAL JUSTICE (correct injustice, care for the weaker ones)

33 _ INDEPENDENT (be self-sufficient and self-confident)

34__MODERATE (avoid extreme feelings and actions)

35 _ LOYAL (be loyal to friends and groups)

36 AMBICIOUS (work hard, have objectives)

37 OPEN (be tolerant to other ideas and beliefs)

38_ HUMBLE (be humble, not self-promoting)

39 _ AUDACIOUS (search for adventure and risk)

40 _ PROTECT THE ENVIRONMENT (preserve nature)

41 INFLUENT (have an impact on people and events)

42 RESPECT PARENTS AND ELEERIY (have a deep respect for seniors

43 _DAYDREAMER (always be optimistic about the future)

44 SELF-DEIERMINED (choose my own objectives)

45 HEALTHY (have good physical and mental health)

46 CAPABLE (be competent, efficient)

47 KNOW YOUR UMITS (submit yourself to the circumstances of life)

48_ HONEST (be sincere, authentic)

49 PRESERVE YOUR PUBUC IMAGE (protect your reputation)

50 OBEDIENT (carry out your tasks and obligations)

51 INTEUGENT (be logical, rational)

52 HELPFUL (work for the wellbeing of others)

53 _ SMART (overcome obstacles to get what you want)

54 SOMEONE WHO ENJOYS UFE (likes to eat, have sex, leisure time, etc)

55 WORSHIPER (have strong religious ties)

56 _ RESPONSIBLE (be reliable, trustworthy)

57 CURIOUS (be interested in everything, have an exploring nature)

58 INDULGENT (be ready to forgive others)

59 SUCCESSFUL (reach your objectives)

60 _ CLEAN (be neat, always clean and ready)

61 SEEF-INDULGENCE (do enjoyable things) 
In this questionnaire you should ask yourself: "Why do I work?" These reasons constitute the work values.

There is a list of work values below. We ask you to assess how important each value is to you as a principle that quides your life at work, putting a number on the left of each value that best expresses your opinion. Use the assessment scale below:

As a principle that guides my life at work, this reason is::

\begin{tabular}{|c|c|c|c|c|}
\hline 1 & 2 & 3 & 4 & 5 \\
\hline Not important & Little important & Important & Very important & Extremely important \\
\hline
\end{tabular}

The higher the number $(1,2,3,4,5)$, the more important is the value as a principle that guides your life at work. Try to differentiate as much as possible the values among themselves using all the numbers. Obviously you can repeat the numbers in your answers/assessments.

\section{It is important for me}

1 _ Financial stability

2 Be financially independent

3 __ Fight social unfaimess

4 __ Have a successful career

5 __ My work means something to me

6 ___ Competitiveness

7 _ Intellectually stimulating job

8 __ Autonomy to determine how to carry out my work

9 __ Be able to support myself financially

$10 \_$Find pleasure in what I do for a living

$11 \quad$ Get to know people

12 _ Personal satisfaction

13 __ Interesting work

$14 \quad$ Intellectual growth

15 F__ Follow the family's profession

16 _ L Like what I do

17 __ Status at work

18 __ Make money
19 __ Be useful for society

20 __ Help my colleagues at work

21 ___ Preserve my health

22 __ Have prestige

23 _ Good relationship with work colleagues

24 _ Identify myself with my work

25 _ Supenise other people

26 _ Friendship with work colleagues

27 _ Compete with work colleagues to achieve my professional goals

28 __ Have a social commitment

29 _ Collaborate to develop society

30 __ Be successful

31 _ Be superior because of the work that I do

32 Change the world

33 __ Be famous

34 ___ Be notorious

35 __ Job stability

36 __ Help others

37 __ Meet material needs

38 __ Face challenges

39 _ Be happy with the work that I do

$40 \ldots$ Variety at work

41 __ Improve my knowledge of my profession

42 _ Win a leading position

43 __ Improve my life conditions

44 Work that requires criativity and innovation

45 Collaborate with work colleagues to achieve the objectives 